\title{
Expression of Cytokeratin 8 in oral squamous cell cancer
}

\author{
Pooja Jaiswal ${ }^{1}$, Yogesh Kumar Yadav ${ }^{2, *}$, Siddhartha Shanker Sinha ${ }^{3}$, Mayank Kumar Singh ${ }^{4}$ \\ ${ }^{1,3}$ Assistant Professor, ${ }^{2,4}$ Associate Professor, Dept. of Pathology, ${ }^{1,2,3}$ Integral Institute of Medical Sciences \& \\ Research, Lucknow, India ${ }^{4}$ Maharani Laxmi Bai Medical College, Jhansi, Uttar Pradesh, India
}

*Corresponding Author:

Email: dr.yogi007@gmail.com

\begin{abstract}
Introduction: Oral cavity cancer is one of the most common cancers in Indian subcontinent. Since conventional methods have limited sensitivity resulting in lower treatment outcomes and higher cost, molecular-based diagnostic markers may be useful in the diagnosis of oral cancer. The objective of this study is to evaluate and compare expression of CK8 in normal oral mucosa as well as well-differentiated, moderately differentiated and poorly differentiated oral squamous cell cancer (SCC).

Materials and Methods: In present study, 148 pathological specimens of histologically proven oral SCC, well differentiated $(n=58)$, moderately differentiated $(n=50)$, poorly differentiated $(n=20)$ oral SCC and normal oral mucosa $(n=20)$ were stained with CK8 by immunohistochemistry. Correlation between different histological types and expression of CK8 was evaluated statistically by Chi- Square Test.

Results: Increased expression of CK8 was seen in oral SCC. Staining intensity and pattern showed variation in various histological grade of oral SCC. The expression of CK8 was correlated with higher histological grading and the results were statistically significant.

Conclusions: CK8 can be used as a predictive marker for malignant transformation and utilized as a prognostic marker by aiding differentiation of histological grades of oral SCC.
\end{abstract}

Keywords: Cytokeratin, Oral Cancer, Squamous cell carcinoma.

Received: $08^{\text {th }}$ June, 2017

Accepted: 02 ${ }^{\text {nd }}$ November, 2017

\section{Introduction}

Oral cancer is one of the ten most common malignancy in the world. Each year about $5,75,000$ new cases and 3,20,000 deaths occur worldwide. ${ }^{1}$

In India, oral cancer is the most common cancer in males and the fifth most common cancer in females. ${ }^{2}$ The majority of malignant tumours in the oral cavity are squamous cell carcinomas (SCC) ${ }^{3}$ It may arise anywhere in the oral cavity, but the common locations are ventral surface of the tongue, floor of the mouth, lower lip, soft palate and gingiva. These malignancies are usually preceded by premalignant lesions such as leukoplakia and erythroplakia.

The aetiology of oral cancer is multifactorial and includes genetic, environment, social and behavioural effects. ${ }^{4}$ Tobacco and alcohol are the two most important risk factors.

Unfortunately, majority of oral cancers lack early signs, and prognosis still remains poor despite of improvements in diagnostic and therapeutic modalities. ${ }^{5}$ This poor outcome may be attributed to presentation at an already advanced stage at the time of diagnosis. ${ }^{6}$ Since histopathology of biopsy is a diagnostic method with limited sensitivity as it is affected by presence of inflammation, lesion site, biopsy technique andsubjective interpretation of the pathologist, ${ }^{7}$ molecular-based diagnostic markers have been employed in the diagnosis of oral cancer.

Cytokeratins (CK) are being used extensively as markers of cell differentiation and in malignancies as an aid to histodiagnosis. CK 8 expression is not observed in stratified adult epithelial tissues. However, they are often aberrantly expressed in carcinomas including oral SCC and their expression is correlated with invasion and poor prognosis. ${ }^{8,9}$

\section{Materials and Methods}

The present study was obtained from various out patients and inpatients admitted in ENT department.

A total of 148 cases diagnosed in Histopathology laboratory between year 2014-2015 were included as follows: 128 cases of Oral Squamous Cell Carcinoma and 20 cases of Benign and Inflammatory oral lesions (controls)

Only biopsy proven cases were included. Inadequate biopsies were excluded from the study. On histological examination lesions were divided into benign and squamous cell carcinoma. Cases of squamous cell carcinoma were further categorized on the basis of histological tumor 
differentiation into well, moderately and poorly differentiated,

For immunohistochemistry sections of 5 micrometre thickness were taken on sialinized slides which were deparaffinized with xylene and dehydrated with ethanol. Antigenic recovery was done with microwave oven using citrate buffer solution. Endogenousblock was carried out with $3 \%$ hydrogen peroxide. The slides were kept moist by moist chamber and primary antibody was added. For every step here after slides were washed with PBS so that false positive results can be prevented. Superenhancer was added for clear signal and then slides were incubated with secondary antibody. DAB chromogen which reacts with secondary antibody and produce colour was then added. Counterstaining was performed with Harrys Haematoxylin.

Staining of negative controls were conducted in the absence of primary antibodies for every detection system. Breast Carcinoma was taken as positive control

\section{Interpretation}

Anti Cytokeratin 8 IHC: Cytoplasmic staining was taken as positive in epithelium. The percentage was classified in two groups (0: no Expression, 1: $\geq 1 \%$ positive expression).

Intensity of staining: To evaluate the intensity of staining in epithelium, grading was done as: (no expression); + (Weak expression); + (Moderate expression); +++ (Maximal expression)

Sample evaluation was performed by two pathologists according to criteria of staining intensities.

\section{Results}

A total of 148 cases were analysed and relevant findings were recorded on a present proforma for further analysis. Majority were well differentiated 58 cases $(45.31 \%), 50$ cases were moderately differentiated $(39.06 \%)$ and 20 cases were poorly differentiated $(15.63 \%)$ (Table 1$)$. CK8 expression (Figure 1 and 2) was seen in majority of poorly differentiated squamous cell carcinoma (16 out of 20 i.e $80 \%$ ) followed by moderately differentiated squamous cell carcinoma (30 out of 50 i.e. $60 \%$ ) and well differentiated squamous cell carcinoma (28 out of 58 i.e. $48.27 \%$ ).

Table 1: Malignant cases (128 cases)

\begin{tabular}{|l|c|c|}
\hline \multicolumn{1}{|c|}{ Histopathological type } & No. of cases & Percentage \\
\hline Squamous cell carcinoma grade I & 58 & 45.31 \\
\hline Squamous cell carcinoma grade II & 50 & 39.06 \\
\hline Squamous cell carcinoma grade III & 70 & 15.63 \\
\hline Total & 128 & 100 \\
\hline
\end{tabular}

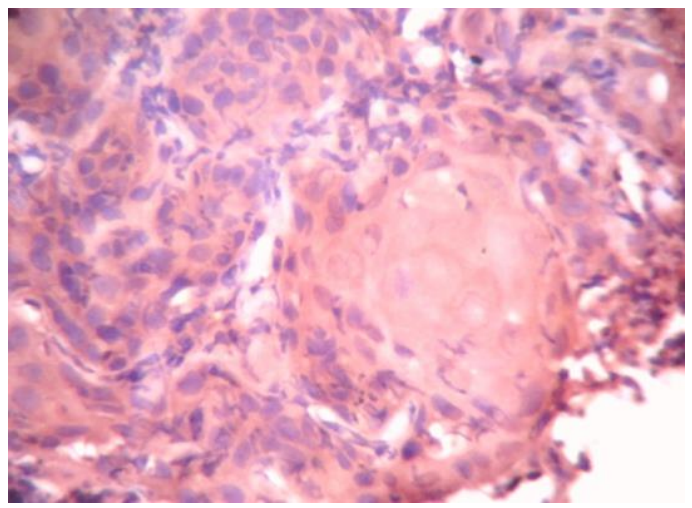

Fig. 1: Immunohistochemical staining of moderately differentiated oral squamous cell carcinoma with cytokeratin 8 . $(x$ 400) 


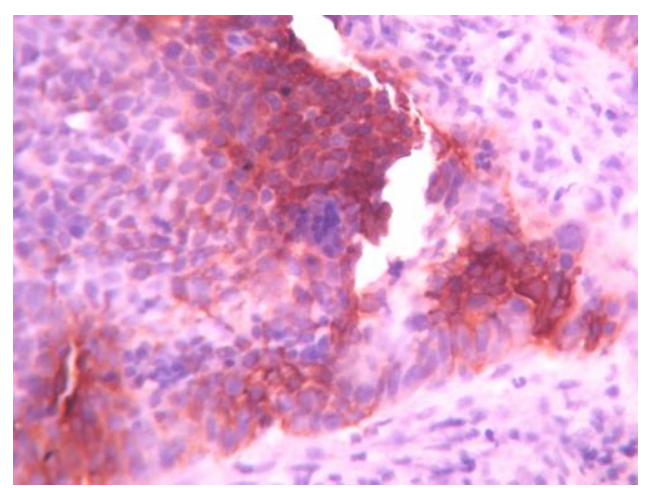

Fig. 2: Immunohistochemical staining of poorly differentiated oral squamous cell carcinoma with cytokeratin 8. $(x$ 400)

Expression of CK8 was found in $57.81 \%$ (74/128) of the oral squamous cell carcinoma. CK8 was absent in $100 \%(n=20)$ of control tissue (Table 2$)$.

Table 2: Presence of CK8 in epithelium of different group

\begin{tabular}{|l|l|c|c|c|c|}
\hline S. No. & \multirow{2}{*}{ Result } & \multicolumn{2}{|c|}{ Control $(\mathbf{n = 2 0})$} & \multicolumn{2}{c|}{ Carcinoma $(\mathbf{n}=\mathbf{1 2 8})$} \\
\cline { 3 - 6 } & & $\mathbf{N}$ & $\mathbf{\%}$ & $\mathbf{N}$ & $\mathbf{\%}$ \\
\hline 1. & Absent & 20 & 100 & 54 & 42.19 \\
\hline 2. & Present & 0 & 0 & 74 & 57.81 \\
\hline
\end{tabular}

No expression of CK8 was seen in 30/58 (51.72\%) cases of well differentiated, 20/50 (40\%) of moderately differentiated and 4/20 (20\%) of poorly differentiated oral squamous cell cancer. Mild intensity of CK8 was seen in 10/58 (17.24\%) of well, 6/50 (12\%) of moderately differentiated oral squamous cell cancer. Moderate intensity of CK8 was seen in 6/58 (10.34\%) of well, 8/50 (16\%) of moderately and $4 / 20(20 \%)$ of poorly differentiated oral squamous cell cancer. Maximal intensity of CK8 was seen in 12/58 (20.7\%) of well, 16/50 (32\%) of moderately and 12/20 (60\%) of poorly differentiated oral squamous cell cancer (Table 3$)$.

Table 3: Differentiation based distribution of CK8

\begin{tabular}{|c|c|c|c|c|c|c|c|c|}
\hline \multirow[t]{3}{*}{ Histopathological type } & \multicolumn{8}{|c|}{ CK8 intensity } \\
\hline & \multicolumn{2}{|l|}{ - } & \multicolumn{2}{|l|}{+} & \multicolumn{2}{|c|}{++} & \multicolumn{2}{|c|}{+++} \\
\hline & $\mathbf{N}$ & $\%$ & $\mathbf{n}$ & $\%$ & $\mathbf{N}$ & $\%$ & $\mathbf{n}$ & $\%$ \\
\hline Well $(\mathrm{n}=58)$ & 30 & 51.72 & 10 & 17.24 & 6 & 10.34 & 12 & 20.7 \\
\hline Moderate $(\mathrm{n}=50)$ & 20 & 40.0 & 6 & 12.0 & 8 & 16.0 & 16 & 32.0 \\
\hline Poor (n-20) & 4 & 20.0 & 0 & 0 & 4 & 20.0 & 12 & 60.0 \\
\hline
\end{tabular}

The chi-square statistic is 15.7677 . The p-value was 0.015057 (Table 4). The result is significant at $\mathrm{p}<$ 0.05 as predictive marker.

Table 4: Test of Significance (Chi-Square Test) for staining and differentiation

\begin{tabular}{|l|c|c|c|c|c|}
\hline $\begin{array}{c}\text { Histopathological } \\
\text { type }\end{array}$ & $\begin{array}{c}\text { Staining } \\
\text { intensity - }\end{array}$ & $\begin{array}{c}\text { Staining } \\
\text { intensity } \\
+\end{array}$ & $\begin{array}{c}\text { Staining } \\
\text { intensity } \\
++\end{array}$ & $\begin{array}{c}\text { Staining } \\
\text { intensity } \\
+++\end{array}$ & Row Totals \\
\hline Well (n=58) & $\begin{array}{c}30(24.47) \\
{[1.25]}\end{array}$ & $\begin{array}{c}10(7.25) \\
{[1.04]}\end{array}$ & $\begin{array}{c}6(8.16) \\
{[0.57]}\end{array}$ & $\begin{array}{c}12(18.12) \\
{[2.07]}\end{array}$ & 58 \\
\hline Moderate (n=50) & $20(21.09$ & $6(6.25)$ & $8(7.03)$ & $16(15.62)$ & 50 \\
{$[0.06]$} & {$[0.01]$} & {$[0.13]$} & {$[0.01]$} & \\
\hline Poor (n-20) & $4(8.44)$ & $0(2.50)$ & $4(2.81)$ & $12(6.25)$ & 20 \\
& {$[2.33]$} & {$[2.50]$} & {$[0.50]$} & {$[5.29]$} & \\
\hline Column Totals & 54 & 16 & 18 & 40 & 128 \\
& & & & & \\
\hline
\end{tabular}




\section{Discussion}

Oral carcinoma represents a major global health problem. High incidence countries for oral cancers include those in South Asia such as Srilanka, India, Pakistan and Bangladesh.Schantz et al (2001) observed that more than $90 \%$ of oral cancers occur in patients over the age of 45 years. ${ }^{10}$ HPV types 16 and 18 have been implicated in oral carcinomas. ${ }^{11}$

The most common site for oral cancer is the tongue $(30 \%)$ followed by lip (17.4\%) and floor of mouth $(16.4 \%) \cdot{ }^{10}$ Buccal mucosa cancer is late to present and typically exophytic.

Cytokeratin (CK) is an intermediate filament found in epithelial cells and an important cytoskeletal component involved in fixation of the nucleus and retainment of cell morphology. There are 20 subtypes of CKs whose expression depends on type of epithelial cell and degree of differentiation. ${ }^{12}$

These CKs are divided into two groups; type I (acidic, CK9-20) and type II (neutral-basic, CK1-8). ${ }^{13}$

The study of the cytokeratin profile by immunohistochemistry is a useful device for diagnosis and characterization of tumor in surgical pathology. ${ }^{14}$

Cytokeratin 8 (CK8) is a structural protein forming intermediate filaments of simple epithelial cells as a dimer with cytokeratin 18 (CK18). ${ }^{15,16}$ CK8 is a tissue-type plasminogen activator which may help in remodelling or infiterating the surrounding tissue. ${ }^{17-19}$

CK8 and CK18 is expressed by normal glandular epithelia, transitional cell epithelium, and liver cells, but not in stratified squamous epithelium. ${ }^{20-23}$

Expressions of CK8 and 18 are seen in fetal buccal mucosa and tongue epithelium till 27 weeks of pregnancy. ${ }^{24}$ Therefore expressions of these CKs by malignant adult mucosa exhibits return towards embryonic pattern of expression. ${ }^{25}$

In breast and colorectal adenocarcinomas reduced expression of CK8/18 is seen, which is associated with tumour progression and bad prognosis. ${ }^{26,27}$ On the contrary, its expression is raised in head and neck cancers, which correlates with adverse results. ${ }^{7,28,29}$

In recent times, it has been proved that the induction of CK 8/18 expression in non-malignant buccal mucosal cells resulted in an important change of phenotypic characteristics after CK $8 / 18$ transfection. ${ }^{30}$ These changes included increase in cellular motility, which indicates an increased tumor aggressiveness and poor prognosis.
CK8 is absent in normal mucosa of oral cavity composed of squamous epithelium. CK8 expression differentiates dysplastic lesions and carcinoma. These features make CK8 helpful in the early detection of pre-malignant lesions, which might progress to overt malignancies. ${ }^{31}$

In our study the common malignant lesions observed were in form of squamous cell carcinoma grade I (45.31\%), followed by squamous cell carcinoma grade II $(39.06 \%)$ and squamous cell carcinoma grade III (15.63\%).

In this study, no expression of CK8 was seen in control tissue. This was in accordance with Christoph mathias et al 2008, who reported CK8 was not detected in normal mucosa $(n=57)$ except for a very mild and incidental expression in cells of stratum basale.CK8 expression was found in $74 / 128(57.81 \%)$ of oral squamous cell carcinoma. ${ }^{32}$ Thomas Fillies et al in 2006 also reported that detectable levels of CK8/18 $(\mathrm{CK} 8 / 18 \geq 1 \%)$ were found in $54 \%(154 / 287)$ of the oral squamous cell carcinoma. ${ }^{33}$

In this study, CK8 expression was seen in $28 / 58(48.28 \%)$ of well, $30 / 50 \quad(60 \%)$ of moderately and 16/20 (80\%) of poorly differentiated oral squamous cell carcinoma. Similarly in a study of 48 patients with biopsy proven squamous cell carcinoma of oral cavity who underwent surgery with neck dissection between 2003-2004, V. Rao et al. 2008 found that in the tumor, aberrant expression of CK8 was seen in $54 \%$, CK1 18 in $44 \%$ and vimentin in $85 \%$.in patients with tumor expressing 8,18 and vimentin, $57 \%$ were poorly differentiated, $36 \%$ moderately and $7 \%$ well differentiated. ${ }^{34}$

In our study, among 128 positive cases majority of them have maximal intensity (80) while 36 cases have moderate intensity and 32 cases have mild intensity. Similar finding was reported by Christoph mathias et al 2008. ${ }^{32}$ However, Sharda S. Sawant et al, 2011 reported CK8, 18 and 19 expression together in oral squamous cell carcinoma. ${ }^{35}$ In their study the positive expression of CK8, 18, 19 was very high $\sim 98 \%$ (48/50). Among positive cases majority of them (30/50) have moderate intensity while 11 cases have maximal intensity and 7 cases have mild intensity.

Thus CK8 expression can be used as a predictive marker for malignant transformation and can be utilized as a prognostic marker by aiding differentiation of histological grades of oral SCC.

\section{Conclusion}

CK8 is known as tumor associated antigen. In the present study tumor cells expressed CK8 to 
strong levels while no expression seen in normal tissue. Hence CK8 can be used as a supportive marker for diagnosis of oral squamous cell carcinoma.

Aberrant expression of CK8 could be correlated with differentiation and recurrence and showed a great promise to be used as prognostic marker for human oral cancer. Further studies with larger sample size will help in establishing these markers in prognostication of oral squamous cell carcinoma.

Further studies on underlying mechanism of the role of CK8 in malignant transformation and regulatory changes might allow development of therapeutic targets for oral cancers.

\section{References}

1. Park K. Epidemiology of chronic non communicable diseases and conditions. In: Park $\mathrm{K}$, editor. Park's text book of Preventive and social medicine. $19^{\text {th }}$ ed. Jabalpur:Banarsi das bhanot;2007.

2. Ferlay J, Soerjomataram I, Ervik M, Dikshit R, Eser S, Mathers C et al. GLOBOCAN 2012 v1.0, Cancer Incidence and Mortality Worldwide: IARC CancerBase No. 11 [Internet]. Lyon, France: International Agency for Research on Cancer;2013.

3. Neville BW, Damm DD, Allen CM, Bouquot JE. Oral \& maxillofacial pathology. 2nd ed. Philadelphia: WB Saunders Co;2002.

4. Wake M. The urban/rural divide in head and neck cancer - the effect of atmospheric pollution. Clin Otolaryngol Allied Sci 1993;18(4):298-302.

5. Dolan RW, Vaughan CW, Fuleihan N. Symptoms in early head and neck cancer: an inadequate indicator. Otolaryngol Head Neck Surg 1998;119(5):463-7.

6. Ellison MD, Campbell BH. Screening for cancer of the head and neck: addressing the problem. Surg Oncol Clin N Am 1999;8:725-34.

7. Fischer DJ, Epstein JB, Morton TH, Schwartz SM. Interobserver reliability in the histopathologic diagnosis of oral pre-malignant and malignant lesions. J Oral Pathol Med 2004 Feb;33(2):65-70.

8. Fillies T, Werkmeister R, Packeisen J, Brandt B, Morin P, Weingart D, Joos U, Buerger H. Cytokeratin 8/18 expression indicates a poor prognosis in squamous cell carcinomas of the oral cavity. BMC Cancer 2006;6:10.

9. Vaidya MM, Borges AM, Pradhan SA, Bhisey AN. Cytokeratin expression in squamous cell carcinomas of the tongue and alveolar mucosa. Eur J Cancer B Oral Oncol 1996;32(5):333-6.

10. Schantz SP, Yu GP. Head and neck cancer incidence trends in young American. A special analysis for tongue cancer. Arch Otolaryngeal Head Neck Surg 2001;128(3):269.

11. Gillison ML, Koch WM, Capone RB, Spafford M, Westra WH, Wu L, et al. Evidence for a causal association between human papillomavirus and a subset of head and neck cancers. J Natl Cancer Inst 2000;92(9):709-20.
12. Chu PG, Weiss LM. Keratin expression in human tissues and neoplasms. Histopathology 2002;40(5):403-39.

13. Hesse M, Magin TM, Weber K. Genes for intermediate filament proteins and the draft sequence of the human genome: novel keratin genes and a surprisingly high number of pseudogenes related to keratin genes 8 and 18 . J Cell Sci 2001;114(14):2569-75.

14. Walid MS, Osborne TJ, Robinson JS. "Primary brain sarcoma or metastatic carcinoma?" Indian J Cancer 2009;46(2):174-5.

15. Leube RE, Bosch FX, Romano V, Zimbelmann R, Hofler H, Franke WW. Cytokeratin expression in simple epithelia. III. Detection of mRNAs encoding human cytokeratins nos. 8 and 18 in normal and tumor cells by hybridization with cDNA sequences in vitro and in situ. Differentiation 1986;33(1):69-85.

16. Magin TM, Vijayaraj P, Leube RE. Structural and regulatory functions of keratins. Exp Cell Res 2007;313(10):2021-32.

17. Hembrough TA, Kralovich KR, Li L, Gonias SL. Cytokeratin 8 released by breast carcinoma cells in vitro binds plasminogen and tissue-type plasminogen activator and promotes plasminogen activation. Biochem J 1996;317(3):763-9.

18. Kralovich KR, Li L, Hembrough TA, Webb DJ, Karns LR, Gonias SL. Characterization of the binding sites for plasminogen and tissue-type plasminogen activator in cytokeratin 8 and cytokeratin 18. J Protein Chem 1998;17(8):845-54.

19. Chu YW, Runyan RB, Oshima RG, Hendrix MJ. Expression of complete keratin filaments in mouse L cells augments cell migration and invasion. Proc Natl Acad Sci USA 1993;90(9):4261-5.

20. Debus E, Moll R, Franke WW, Weber K, Osborn M. Immunohistochemical distinction of human carcinomas by cytokeratin typing with monoclonal antibodies. Am J Pathol 1984;114(1):121-30.

21. Schaafsma HE, Ramaekers FC, van Muijen GN, Lane EB, Leigh IM, Robben H, et al. Distribution of cytokeratin polypeptides in human transitional cell carcinomas, with special emphasis on changing expression patterns during tumor progression. Am J Pathol 1990;136(2):329-43.

22. Trask DK, Band V, Zajchowski DA, Yaswen P, Suh T, Sager R. Keratins as markers that distinguish normal and tumor-derived mammary epithelial cells. Proc Natl Acad Sci USA 1990;87(6):2319-23.

23. Schussler MH, Skoudy A, Ramaekers F, Real FX Intermediate filaments as differentiation markers of normal pancreas and pancreas cancer. Am J Pathol 1992;140(3):559-68.

24. Vaidya MM, Sawant SS, Borges AM, Naresh NK, Purandare MC, Bhisey AN. Cytokeratin expression in human fetal tongue and buccal mucosa. J Biosci 2000;25:235-42.

25. Fillies T, Jogschies M, Kleinheinz J, Brandt B, Joos U, Buerger H. Cytokeratin alteration in oral leukoplakia and oral squamous cell carcinoma. Oncol Rep 2007;18(3):639-43.

26. Woelfle U, Sauter G, Santjer S, Brakenhoff R, Pantel K. Down-regulated expression of cytokeratin 18 promotes progression of human breast cancer. Clin Cancer Res 2004;10(8):2670-4. 
27. Knosel T, Emde V, Schluns K, Schlag PM, Dietel $\mathrm{M}$, Petersen I. Cytokeratin profiles identify diagnostic signatures in colorectal cancer using multiplex analysis of tissue microarrays. Cell Oncol 2006;28:167-75.

28. XC, Lee JS, Lippman SM, Ro JY, Hong WK, Lotan R. Increased expression of cytokeratins CK8 and CK19 is associated with head and neck carcinogenesis. Cancer Epidemiol Biomarkers Prev 1995;4(8):871-6.

29. Gires O, Munz M, Schaffrik M, Kieu C, Rauch J, Ahlemann $\mathrm{M}$ et al. Profile identification of disease-associated humoral antigens using AMIDA, a novel proteomics-based technology. Cell Mol Life Sci 2004;61(10):1198-207.

30. Raul U, Sawant S, Dange P, Kalraiya R, Ingle A, Vaidya M. Implications of cytokeratin 8/18 filament formation in stratified epithelial cells: induction of transformed phenotype. Int J Cancer 111(5):662-8.

31. Reichart PA, Philipsen HP. Oral erythroplakia - a review. Oral Oncol 2005;41(6):551-61.

32. Christoph Matthias, Brigitte Mack, Alexander Berghaus,and Olivier Gires. Keratin 8 expression in head and neck epithelia. BMC Cancer 2008;8:267.

33. Thomas Fillies, Richard Werkmeister, Jens Packeisen, Burkhard Brandt, Philippe Morin, Dieter Weingart et al. Cytokeratin 8/18 expression indicates a poor prognosis in squamous cell carcinomas of the oral cavity. BMC Cancer 2006;6:10.

34. V.Rao, D.Chaukar, M.Vaidya, S.Sawant, A.Dcruz, S.Kane. Role of cytokeratin and vimentin as prognostic markers in oral cancers. $\mathrm{J}$ Clin Oncol 2008:26;17030.

35. Sharada S. Sawant, Devendra A. Chaukar, Shreyas S. Joshi, Prerana P. Dange, Sadhana Kannan, Shubhada Kane et al. Prognostic value of tissue polypeptide antigen in oral squamous cell carcinoma. Oral Oncology 2011;47:114-20. 